\title{
TNNI3 wt Allele
}

National Cancer Institute

\section{Source}

National Cancer Institute. TNNI3 wt Allele. NCI Thesaurus. Code C104224.

Human TNNI3 wild-type allele is located in the vicinity of 19q13.4 and is approximately 6 $\mathrm{kb}$ in length. This allele, which encodes troponin I, cardiac muscle, plays a role in muscle filament sliding. 